Research Article

\title{
Analytical Standardization of Kaphaketu Ras
}

\author{
1 Jaya Prakash N, ${ }^{2}$ Ramesh babu, ${ }^{3}$ Venkata Subbaiah K \\ 1PG Scholar final year, Department of Rasa Shastra \& Bhaishajya Kalpana, \\ ${ }^{2}$ Assisstant Professor, Department of Rasa Shastra \& Bhaishajya Kalpana, \\ S.V. Ayurvedic College, Tirupati, Andhra Pradesh, India. \\ ${ }^{3}$ Scientist, Department of Science and Technology, PURSE, Sri Venkateswara University, Andhra Pradesh, India. \\ *Corresponding author's E-mail: neerugattijaya@gmail.com
}

Received: 18-01-2021; Revised: 26-02-2021; Accepted: 02-03-2021; Published on: 20-03-2021.

\begin{abstract}
Rasa shastra is a branch of medicine which deals with preparation of drugs of metals and minerals having wide range of therapeutic efficacy and possessing innate qualities like quick action, less dose, tastelessness, prolonged shelf life and better palatability. Kaphaketu Ras is one such Rasaoushadhi mentioned in Rasayoga Sagara indicated in Pinasa, Kasa, Swasa, Gala roga, Danta Roga, Karna roga and Netra roga. It contains Shanka bhasama, Shodhita Tankana, Shodhita Vatsanabha and Pippali churna. Shodhana, Marana and Churna Nirmana are the main pharmaceutical procedures involved in the preparation of Kaphaketu Ras. The objective of this study is to assure the safety and to understand about the identity, form, particle size and surface morphology of the above formulation, it was subjected to analysis through various techniques like X-ray diffraction (XRD), Scanning electron microscopy (SEM), Energy dispersive X-ray spectroscopy (EDS), Particle size analysis (PSA), Zeta Potential (ZP), UV-Spectroscopy, Fourier transform InfraRed spectroscopy (FTIR) and Inductively Coupled Plasma - Optical Emission Spectrometry (ICP-OES). XRD of Kaphaketu Ras showed major peaks of $\mathrm{CaCO}_{2}$ (Calcite) compound with Rhombohedral structure and minor peaks of $\mathrm{Mg}_{3} \mathrm{Ca}\left(\mathrm{CO}_{3}\right)_{4}$. SEM micrographs showed agglomeration of irregular shaped particles at $5 \mathrm{KX}$ and $3 \mathrm{KX}$ magnifications. EDS analysis confirmed the significant presence of elements viz. $\mathrm{O}-71.96 \%, \mathrm{Na}-11.71 \%, \mathrm{~K}-2.23 \%, \mathrm{Ca}-13.29 \%, \mathrm{Cl}-0.71 \%$. Particle size was found to be $363.2 \mathrm{~nm}$ with Zeta Potential of $-14 \mathrm{mV}$. UV- Spectrum of Kaphaketu Ras showed maximum absorption at $310 \mathrm{~nm}$. FTIR test showed 10 peaks between the wavelengths 3415.15 to $429.18 \mathrm{~cm}^{-1}$. ICP analysis revealed high presence of Boron, Sodium, Potassium and Calcium with 17393.80 , 2235.86, 1823.92 and 7030.50 ppm respectively.
\end{abstract}

Keywords: Kaphaketu ras, Rasayoga Sagara, Analytical studies, Safety, XRD, SEM, FTIR, ICP-OES.

QUICK RESPONSE CODE $\rightarrow$

DOI:

10.47583/ijpsrr.2021.v67i01.021

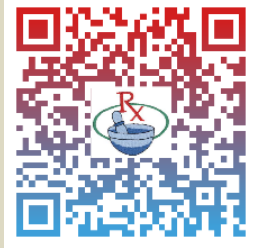

DOI link: $\underline{\text { http://dx.doi.org/10.47583/ijpsrr.2021.v67i01.021 }}$

\section{INTRODUCTION}

A yurvedic drugs are time tested for their efficacy and need no validation for their administration to patients. But, in present era there is change in mind set of patients. Safety of the drug to be administered is par with its efficacy. Kaphaketu Ras is one such Rasa Oushadi described in classics Rasa Yoga Sagara for the management of Dusta Pratisyaya ${ }^{1}$. It contains Shanka Bhasma as the main ingredient along with ingredients like Pippali (Piper longum), Shodhita Vatsanabha (Aconitum ferox) and Shodhita Tankana (Borax). In Ayurveda the metals $\&$ minerals are made into biocompatible form by certain detoxification processes like Shodhana, Marana, Bhavana etc. which remove the toxic potential from metals \& minerals and imparts them with therapeutic efficacy of a high grade.
Classical texts have enumerated certain tests which ensure the proper transformation of basic metal and mineral into bioabsorbable Bhasma form. Analytical study is mandatory to check the raw samples, intermediary products and final product. The presence of free metal in any formulation can lead to damage of vital organs of the body. Hence highly sensitive modern parameters are employed for gaining information about identity, form, particle size and structure of contents of the formulation. By taking this into consideration, an attempt has been made to analyze Kaphaketu Ras through X-ray diffraction, Scanning electron microscopy, Energy dispersive X-ray spectroscopy, Particle size analysis, Zeta Potential, UVSpectroscopy, Fourier transform Infra-Red spectroscopy and Inductively Coupled Plasma - Optical Emission Spectrometry.

\section{MATERIALS AND METHODS}

Shankha, Pippali and Vatsanabha was obtained from TTD's Sri Srinivasa Ayurveda Pharmacy, Tirupati. Tankana was obtained from local market, Tirupati. Entire preparation of Kaphaketu Ras was carried out in TTD's Sri Srinivasa Ayurveda Pharmacy and Department of Rasa Shastra and Bhaishajya Kalpana, S.V.Ayurvedic College, TTD, Tirupati. 


\section{Requirement for XRD}

Model- Powder X-Ray Diffract meter D8 advance, Manufacturer- Bruker Germany. SEM and EDS: ModelEVO MA 15, Manufacturer- Carl Zeiss - Germany; PSA and ZP: Model- Horiba scientific Particle Size and Zeta Potential Analyzer, Manufacturer- Horiba instruments, Irvine, CA 92618 USA; UV- Spectroscopy: Model- Nano drop 8000 Spectrophotometer, Manufacturer- Thermo Scientific, India ; ICP-OES: Model- Agilent 725, Manufacturer- Agilent technologies, USA.

\section{Pharmaceutical process}

The main pharmaceutical procedures involved in the preparation of Kaphaketu ras are Shodhana, Marana, Bhavana, and Churna nirmana. Ashudha Shankha(400g) was made into small pieces and placed in Pottali. It was subjected to Dolayantra Swedana ${ }^{2}$ for 12 hours in Nimbu swarasa media. Then the Shodhita Shankha (390g) was subjected to three Gaja puta to get Shankha Bhasma ${ }^{3}$ (320g). Ashudha Tankana (500g) was taken in clean Khalwa yantra and subjected to Nirjalikarana process by heating with medium fire ${ }^{4}$. After stoppage of crackling sounds, heating was stopped and Shudha Tankana (320g) was collected. Ashudha Vatsanabha (500g) was taken, cut into small pieces and made into Pottali. The Pottali was suspended in a vessel containing Gokshira and subjected to heating on Mandagni for 6 hours ${ }^{5}$. Later it was removed and washed with hot water to get Shudha Vatsanabha (350g). Churna nirmana was done for Pippali, Vatsanabha (300g each). Fine powder of Pippali, Vatsanabha, Tankana and Shankha Bhasma were taken in equal quantites in Khalwa Yantra and made into homogenous mixture of Kaphaketu ras. It was triturated with Ardraka Swarasa for 3 days and dried. Then the mixture was filled in capsules of $125 \mathrm{mg}$.

\section{Analysis of Kaphaketu Ras using modern parameters}

\section{X-Ray Diffraction (XRD)}

Kaphaketu Ras was subjected to XRD at Department of Physics, Yogi Vemana University, Kadapa and Andhra Pradesh.

\section{Procedure}

Sample was powdered in agate mortar to very fine powder and it was mounted in sample tray of machine. X-Ray beam bearing a wavelength of $1.5418740 \mathrm{~A}^{\circ}$ from copper source is passed on the sample. Detector was set to identify diffracted beams between $10-70$ degrees of 2 range. Obtained soft files of XRD consisting values of $2 \theta$ and intensity are plotted on a graph ( $2 \theta$ on X-Axis and Intensity of Y-Axis) using "Origin Pro 8.5 SR2" Data Analysis Software. Various compounds consisting similar diffraction pattern were identified by matching their peaks with corresponding JCPDS Crystallographic cards. For even better accuracy and precision, XRD soft files were also analyzed for corresponding phase/entry matching with Crystallographic Open Data base (COD - 20120320) - USA, after plotting values in Analytical X'pert high score plus software 3.0.0.123, UK.

\section{Scanning Electron Microscopy and Energy dispersive X- Ray spectroscopy}

The practical was performed at Department of Physics S.V University, Tirupati.

\section{Procedure of SEM}

Specimen of the sample to be analyzed was directly kept on the specimen holder for visualization. As the sample employed has nonconductive nature, the sample surface was coated by carbon by arc melting technique. Then the dried powder was observed under the microscope at $1,000 \mathrm{X}$ to $7,000 \mathrm{KX}$ and the micrographs were taken with the inbuilt camera.

\section{Procedure of EDS}

Electron beam excitation is used in scanning electron microscopes (SEM). A detector is used to convert X-ray energy into voltage signals; this information is sent to a pulse processor, which measures the signals and passes them onto an analyzer for data display and analysis. The detector used in EDS is often the Lithium drifted Silicon detector which is operated at liquid nitrogen temperatures. Sample of Kaphaketu Ras was placed on the specimen holder and subjected to Energy-Dispersive X-ray spectroscopy (EDS). When the sample was bombarded by the SEM's electron beam, electrons are ejected from the atoms comprising the sample's surface. The resulting electron vacancies are filled by electrons from a higher state, and an X-ray is emitted to balance the energy difference between the two electrons' states. The X-ray spectrum thus acquired gives the information on the elemental composition of the material under examination.

\section{Particle Size Analysis and Zeta Potential}

The practical was conducted at Department of science and Technology, PURSE, S.V. University, Tirupati.

\section{Procedure of PSA}

The sample was mixed in water and sonicated for 10 minutes. Then it was poured into the sample chamber, where it passes through the laser beam as homogeneous stream of particles. The scattering of light occurs over a wide range of angles upon interacting with the particles in the suspension which are moving by Brownian motion. Based on this scattering pattern of sample, particle size distributions are calculated comparing with appropriate optical model.

\section{Procedure of ZP}

A $1 \%$ concentration of Kaphaketu Ras was prepared in distilled water. The particles were well dispersed before analysis and the sample was taken in a $1 \mathrm{ml}$ syringe and injected slowly into the capillary cell (cuvette) through the sample port. Care was taken to see that air bubbles are not formed during this process. As the sample comes out from the second port of the capillary cell, the injection process is 
stopped. This indicates complete filling of the sample into the capillary cell. The sample ports are then covered with lids and the capillary cell was then placed into the sample holder of the zeta sizer instrument for analysis.

\section{UV-Spectroscopy}

Practical was performed at Department of science and Technology, PURSE, S.V. University, Tirupati.

\section{Procedure}

$5 \mathrm{~g}$ of Kaphaketu Ras was macerated with $100 \mathrm{ml}$ of solvent in a closed flask for twenty-four hours, shaking frequently during six hours and allowed to stand for eighteen hours. It was filtered, taking for UV spectroscopic study. The Spectra was taken at $200-800 \mathrm{~nm}$ from the peak obtained the $\lambda$ max value was calculated.

\section{Fourier Transform Infrared Spectroscopy (FT-IR)}

This practical was conducted at Padmavathi Mahila University, Tirupati.

\section{Procedure}

\section{RESULTS}

\section{RESULTS}

X-Ray Diffraction Studies (XRD)
Sample was placed in the Potassium bromide plate of FTIR spectrometer and the interference pattern was detected by the infrared detector as variations in the infrared energy level, and the obtained spectral information was calculated.

\section{Inductively Coupled Plasma - optical Emission Spectrometry}

This practical was performed at Centre for material for electronics technology (C-MET), Department of Electronics and Information technology, Hyderabad.

\section{Procedure}

$0.2 \mathrm{~g}$ of Kaphaketu Ras was taken in Teflon tubes and added $6.0 \mathrm{ml}$ of Nitric acid and $2.0 \mathrm{ml}$ of Hydrogen peroxide and allowed for 10 minutes in outside for reaction. Then samples were dissolved using Microwave Digestion System (Anton Par Multi wave 3000). Then Kaphaketu Ras solutions were made to $25.0 \mathrm{ml}$ and filtered. These solutions were used for Elemental analysis using ICP-OES instrument.

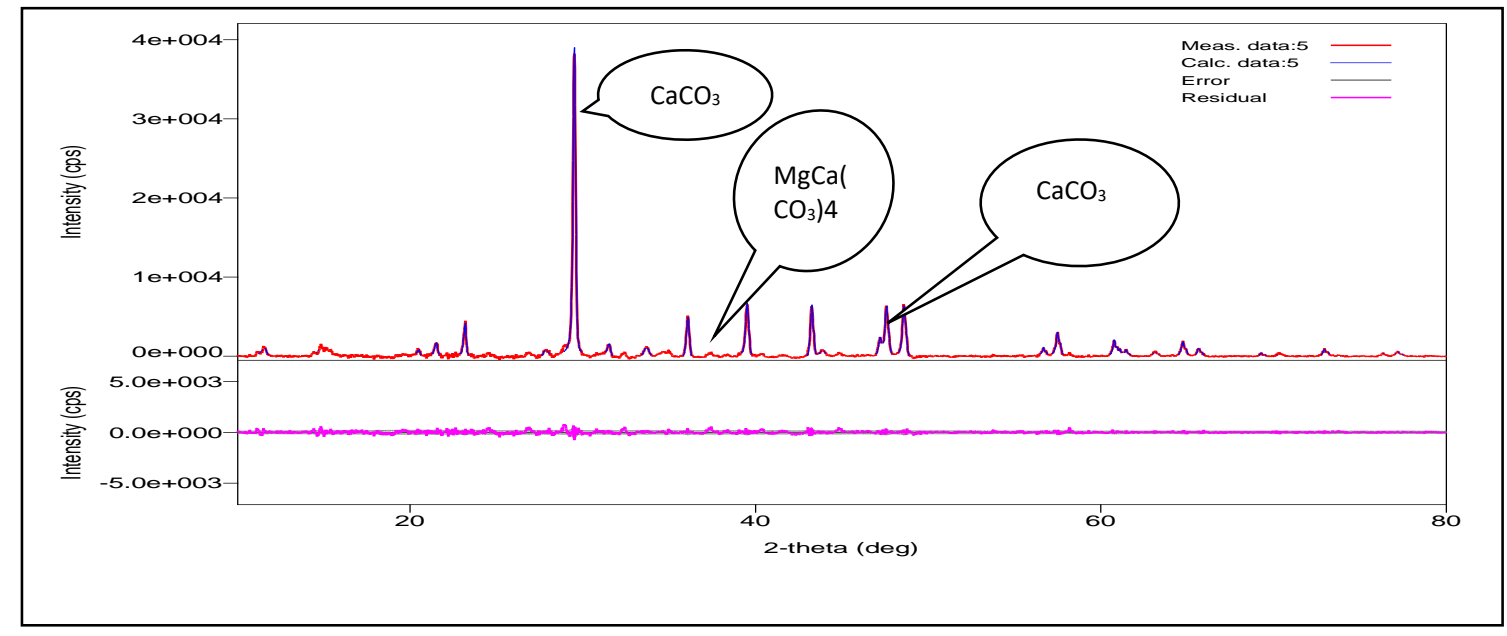

Figure 1: Showing XRD peaks of Kaphaketu Ras

- $\quad \mathrm{XRD}$ of KaphaKetuRas shows that major peaks are of $\mathrm{Ca} \mathrm{CO}_{3}$ (Calcite) compound with Rhombohedral structure and minor peaks ofMg $33 \mathrm{Ca} \quad\left(\mathrm{CO}_{3}\right)_{4}$ (Calcium Magnesium Carbonate) with Rhombohedral structure. The $\mathrm{Ca} \mathrm{CO}_{3}$ peaks are detected at diffractive angle of 29.51, 48.58, and 39.54. $\mathrm{Mg}_{3} \mathrm{Ca}\left(\mathrm{CO}_{3}\right)_{4}$ peaks is detected at 31.55 The JCPDS reference numbers are 01-072-1650,

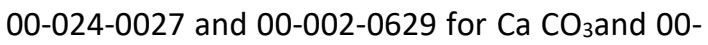
014-0409 for $\mathrm{Mg}_{3} \mathrm{Ca}\left(\mathrm{CO}_{3}\right)_{4}$
Scanning Electron Microscopy

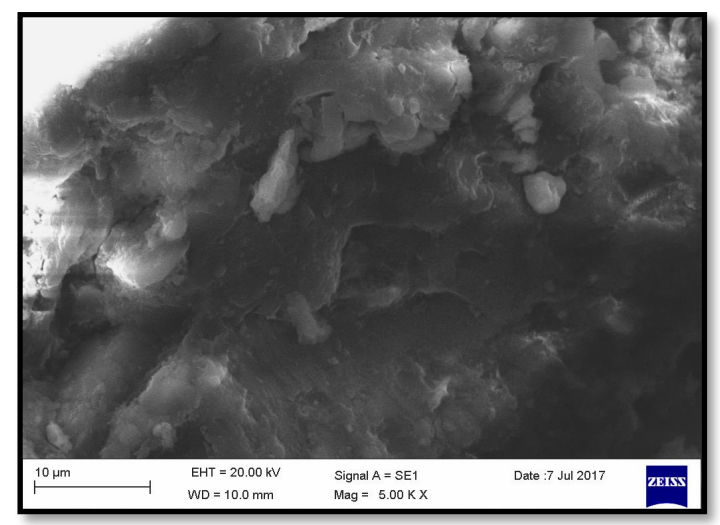

Figure 2: Showing SEM result of Kaphaketu Ras (Mag. 5 $\mathrm{KX})$ 
- The SEM images of KaphaKetu Ras at $5 \mathrm{~K}$ magnifications showed agglomeration of irregular shaped particles.

\section{Energy Dispersive X-Ray Spectroscopy}

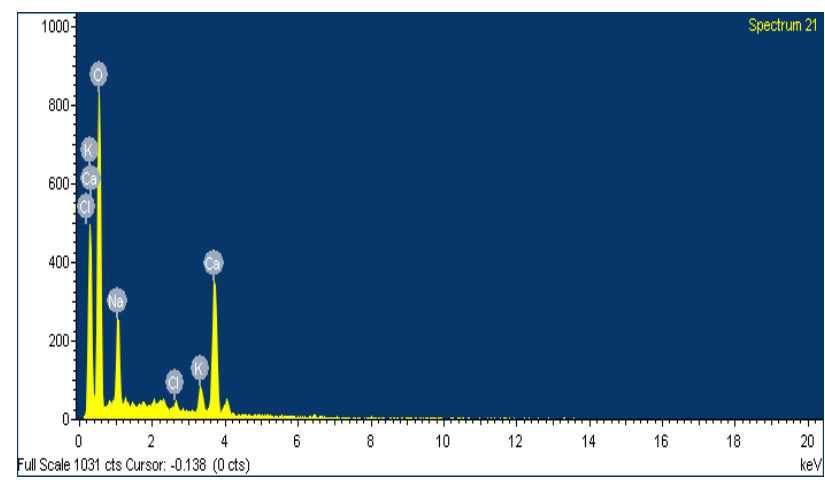

Figure 3: Showing EDS graph of Kaphaketu Ras

- EDS analysis of KaphaKetu Ras confirmed the presence of elements viz. $\mathrm{O}-\mathbf{7 1 . 9 6} \%, \mathrm{Na}-$ $11.71 \%, \mathrm{~K}-2.23 \%, \mathrm{Ca}-13.29 \%, \mathrm{Cl}-0.71 \%$.

\section{Particle Size Analysis}

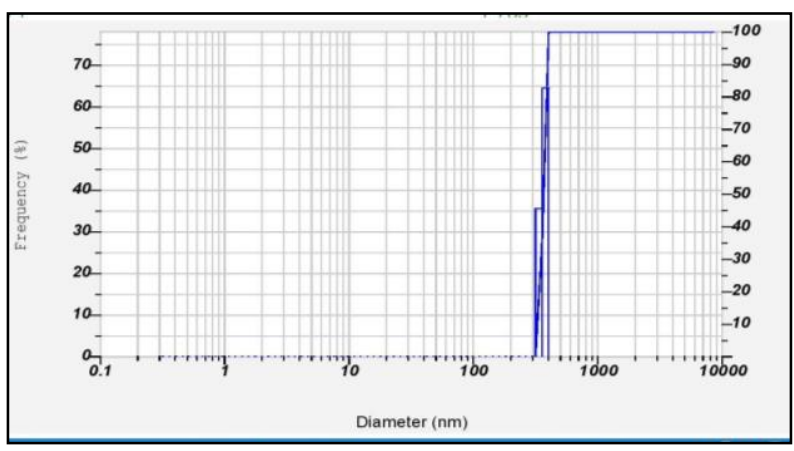

Figure 4: Showing the result of Particle size analysis of Kaphaketu Ras

The mean particle size of Kaphaketu Ras is $363.2 \mathrm{~nm}$.

\section{Zeta Potential}

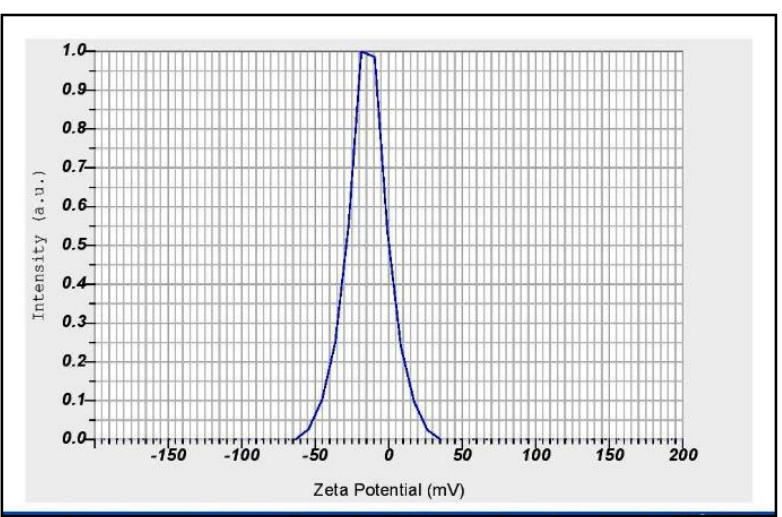

Figure 5: Showing Zeta potential distribution of Kaphaketu Ras

- The Zeta Potential (mean) value of KaphaKetu Ras found to be $\mathbf{- 1 4 m V w h i c h ~ i n d i c a t e s ~ i t s ~ l o w ~}$ colloidal stability.

\section{UV- Spectroscopy}

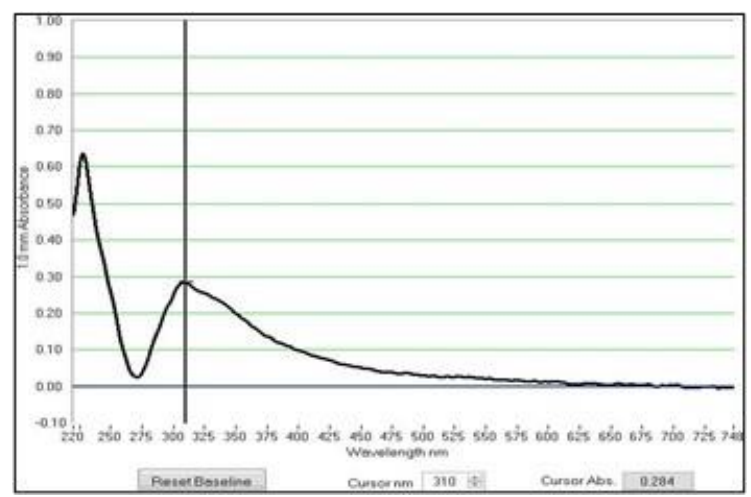

Figure 6: Showing UV-Spectrum of Kaphaketu Ras

- UV- Spectrum of KaphaKetu Ras showed maximum absorption at $310 \mathrm{~nm}$.

\section{Fourier Transform Infrared Spectroscopy (FT-IR)}

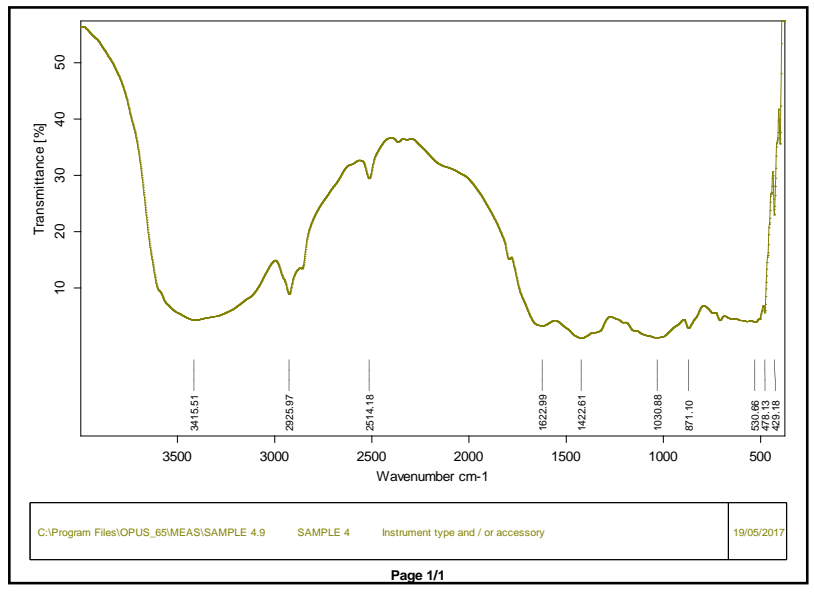

Figure 7: Showing various peaks obtained in FTIR analysis of Kaphaketu Ras

\section{Inductively Coupled Plasma - Optical Emission Spectrometry}

Table 1: Showing the result of ICP-OES analysis of Kaphaketu Ras.

\begin{tabular}{|r|c|c|}
\hline S. No. & $\begin{array}{c}\text { Name of the } \\
\text { elements analysed }\end{array}$ & $\begin{array}{c}\text { Tests results in } \\
\text { ppm }\end{array}$ \\
\hline 1. & Silver & 4.44 \\
\hline 2. & Arsenic & Not detected \\
\hline 3. & Boron & 17393.80 \\
\hline 4. & Calcium & 7030.50 \\
\hline 5. & Cadmium & Not detected \\
\hline 6. & Chromium & 3.10 \\
\hline 7. & Copper & 8.54 \\
\hline 8. & Iron & 293.74 \\
\hline 9. & Mercury & 7.57 \\
\hline 10. & Potassium & 1823.92 \\
\hline 11. & Magnesium & 888.25 \\
\hline
\end{tabular}




\begin{tabular}{|c|c|c|}
\hline 12. & Manganese & 28.44 \\
\hline 13. & Sodium & 2235.86 \\
\hline 14. & Phosphorus & 109.88 \\
\hline 15. & Lead & 22.71 \\
\hline 16. & Sulphur & 706.52 \\
\hline 17. & Selenium & Not detected \\
\hline 18. & Tin & 5.63 \\
\hline 19. & Zinc & 12.59 \\
\hline
\end{tabular}

\section{DISCUSSION}

Analytical study is an essential part of any research work. It provides us with experimental data (qualitative and quantitative) and makes us know about certainty of our assumptions and prevents from miss interpretations. It gives us the knowledge about identity, size, structure of chemical constituents and physical properties. It hints us about toxic properties of drugs, if any.

- X-ray diffraction has been in use in two main areas, for the fingerprint characterization of crystalline materials and the determination of their structure. Each crystalline solid has its unique characteristic Xray powder pattern, which may be used as a "fingerprint" for its identification. Once the material has been identified, $\mathrm{X}$ - ray crystallography may be used to determine its structure, i.e. how the atoms pack together in the crystalline state and what the inter-atomic distance and angle. X-ray diffraction is one of the most important characterization tools used in solid state chemistry and materials science. Size and the shape of the unit cell for any compound can be detected most easily using the diffraction of X-rays. Major peaks of Calcite and Magnesium carbonate were seen in XRD. During Shodhana and Marana process of Shankha reacts with oxygen to form above compounds.

- Scanning electron microscopy (SEM) is an analytical technique to know the surface morphology of the drug. It uses electron beam rather than light to form a Figure. It is capable of producing high resolution figures of a sample surface, which means that closely spaced features can be examined at a high magnification. Due to the manner in which the Figure is created, SEM Figures have a characteristic three dimensional appearance and are useful for determining the surface structure of the sample i.e. topography. It can magnify objects to extreme levels where even structure of nano particles could be clearly visible. Clear demarcation of particles was not visible in the SEM micrographs of KaphaKetu ras due to agglomeration of irregular shaped particles.

- Energy-Dispersive X-ray spectroscopy (EDX) is an analytical technique used for elemental analysis or chemical characterization of a sample. It relies on the investigation of an interaction of some source of X-ray excitation and a sample. The presence of Sodium, Calcium, Potassium, Oxygen, Carbon is witnessed due to presence of Shanka, Borax and herbal ingredients of the formulation.

- The size of the particles in the drug plays major role in its therapeutic action and efficacy. Particle size and surface area of solid drug are inversely related to each other. The mean particle size of the particles of Kaphaketu ras is $363.2 \mathrm{~nm}$. The nano size of this drug is indicative of its quick absorption and faster dispersion into body resulting in better therapeutic efficacy.

- Zeta potential is a measure of the magnitude of the electrostatic or charge repulsion or attraction between particles and is one of the fundamental parameters known to affect stability. The Zeta Potential (mean) value of Kaphaketu Ras was found to be $-14 \mathrm{mV}$ which indicates low colloidal stability.

- UV-Spectroscopy refers to absorption spectroscopy or reflectance spectroscopy in the ultraviolet-visible spectral region. Different molecules absorb radiation of different wavelengths. An absorption spectrum will show a number of absorption bands corresponding to structural groups with the molecule. Electromagnetic spectrum of U.V region is from 190 to $400 \mathrm{~nm}$ whereas for visible region it is $400-800 \mathrm{~nm}$. UV- Spectrum of Kaphaketu Ras showed maximum absorption at 310 $\mathrm{nm}$.

- FTIR was performed to detect the presence of functional groups or organic legends in Kaphaketu Ras. Infrared spectroscopy deals with the infrared region of the electromagnetic spectrum that is light with a longer wavelength and lower frequency than visible light. When infrared light or radiation hits a molecule, the bonds in the molecule absorb the energy of the infrared and respond by vibrating. Kaphaketu Ras showed 10 peaks between the wavelength $3415.51 \mathrm{~cm}^{-1}$ to $429.18 \mathrm{~cm}^{-1}$. of 3415.51 to 429.18. O-H stretching bond is observed at the wave number of 3415.51 . It indicates the presence of alcohols. $\mathrm{C}-\mathrm{H}, \mathrm{C}-\mathrm{N}$ and $\mathrm{N}-\mathrm{H}$ stretching bonds were observed in between the wave numbers of 1622.99, 2514.18, 2925.97 and 1030.88. It indicates the presence of alkyl and primary amine groups. $\mathrm{C}-\mathrm{H}$ bond is observed in the region of 871.10 wave number, indicates the presence of aromatic compounds. C-X bond at 530.66 wave number indicates the presence of bromoalkanes.

- ICP-OES is one of the most powerful and popular analytical tool for the determination of trace elements in a sample. It is very useful for standardization as well as to develop analytical profile. The ICP-OES analysis of KaphaKetuRas showed high presence of Boron 17393.80, Sodium 2235.86, Potassium 1823.92 and Calcium 7030.50. This may be due to presence of Boron, Calcium and Potassium in Shankabhasma and 
Tankan. The heavy metals like Cadmium, Selenim were not detected. The metals like Mercury 7.57, Lead 22.71 and Chromium 3.10 were present in less proportion only. The presence of Magnesium 888.25, Manganese 28.44, Phosphorus 109.88, Iron 293.74, Tin 5.63 and Zinc 12. 59 due to presence of all these elements in Pippali,Ardraka and Vatsanabha.

\section{CONCLUSION}

The present study confirms the fact that Kaphaketu ras is a herbo-mineral compound which shows the presence of Calcium carbonate and Magnesium carbonate. Presence of other micro essential elements may be due to the herbal ingredients used in the process of preparation and from the component drugs of Kaphaketu Ras. These entire analytical tests justify the structural and chemical composition of the compound indicating its safety and efficacy and devoid of any toxic components.

\section{REFERENCES}

1. Vaidya Pandit Hariprapana ji - Rasa Yoga Sagara Volume 1 Kha karadi rasa; Slokha No. 226-228: Krishna das Academy, Varanasi, Reprint 2004.

2. Pandit Kasinath Shastry, Sri Sadananda sharma Virachitha Rasa Tarangini, Taranga 12, Verse no.6-8, Varanasi: Motilal Banarasidas, 2014; p-285.

3. Pandit Kasinath Shastry, Sri Sadananda sharma Virachitha Rasa Tarangini, Taranga 12, Verse no. 17-18, Varanasi: Motilal Banarasidas, 2014; p-287.

4. Pandit Kasinath Shastry, Sri Sadananda sharma Virachitha Rasa Tarangini, Taranga 13, Verse no. 77-78, Varanasi: Motilal Banarasidas, 2014; p-358.

5. Pandit Kasinath Shastry, Sri Sadananda sharma Virachitha Rasa Tarangini, Taranga 24, Verse no. 23-24, Varanasi: Motilal Banarasidas, 2014; p-652.

\section{Source of Support: None declared.}

Conflict of Interest: None declared.

For any question relates to this article, please reach us at: editor@globalresearchonline.net New manuscripts for publication can be submitted at: submit@globalresearchonline.net and submit_ijpsrr@rediffmail.com 